This article appeared as:

Davidse, Kristin, Simon De Wolf \& An Van linden. 2015. The development of (there/it is / I have) no doubt expressing modal and interactional meaning. Journal of Historical Pragmatics 16 (1): 25-58.

\title{
The development of the modal and discourse marker uses of (there/it is/I have) no doubt
}

\author{
Kristen Davidse, Simon De Wolf, and An Van linden \\ University of Leuven, University of Leuven, and University of Leuven \& \\ Research Foundation Flanders (FWO)
}

\begin{abstract}
In this article we reconstruct the emergence of the modal and discourse marker uses of adverbial and clausal expressions with no doubt. Their history contrasts in a number of surprising ways with typical grammaticalization hypotheses. Existential expressions with no doubt emerged directly with grammatical modal meaning and developed lexicalized idiomatic uses later on. We account for this in terms of Boye and Harder's discourse approach to grammaticalization and lexicalization, according to which the former involves coded discourse secondariness whereas the latter expresses a primary point of the discourse. Like adverbial no doubt, I have/make no doubt acquired not only modal but also discourse marker uses. Invoking the principles of Kaltenböck, Heine and Kuteva's Thetical Grammar, we explain this development in terms of the positional and scopal flexibility, and the discourse functionality of these expressions.
\end{abstract}

Keywords: grammaticalization, modality, discourse marker, coded discourse secondariness, Thetical Grammar

\section{Introduction}

In Present-day English, the string no doubt is used mainly as a marker of the speaker's modal commitment to a proposition, e.g. (1)-(2), or as a discourse marker, as in (3) and (4). 
(1) There's no doubt, Peter Mandelson is a disaster. (WB) ${ }^{1}$

(2) Some form of education among the workforce was no doubt valuable and even prudent. (WB)

(3) "[...] I thank you, Mister Sharpe," Cromwell said gravely, "for you have made my mind easier."

Sharpe also stood, ducking his head under the low beams. "Thank you, sir."

"I've no doubt I'll see you at dinner soon. [...]" (WB)

(4) The trailer for Channel 4's SARS: Killer Bug documentary [...] pins the whole outbreak on somebody sneezing in a Hong Kong lift in February. SARS is coming out from under the shadow of Gulf War II, and no doubt we can look forward to more programmes from now on. (WB)

Modal assessments can be expressed both by clausal forms, e.g. there is no doubt in (1), and by adverbial no doubt, as in (2). Discourse markers can be recognized by the erosion of epistemic meaning, over and above which interactional relations and interpersonal stance are conveyed (SimonVandenbergen and Aijmer 2007, 301). In (3), I've no doubt does not so much signal the speaker's epistemic commitment as it acts as an invitation to the addressee to confirm his suggestion. In (4), no doubt does not function as an epistemic marker either, but conveys interpersonal stance: the original meanings of certainty and predictability are twisted to convey irony and ridicule (Simon-Vandenbergen and Aijmer 2007, 301). Only I have no doubt and no doubt are used as discourse markers. Much less commonly, the clausal forms are also used lexically, e.g. there is no doubt in (5), which contrasts an issue that is "open to debate" with one about which there is "no doubt".

(5) Brown stands accused of not promoting enough young players, Vogts of over-promoting them. Whatever happens to be the worst crime is open to debate, but there is no doubt that what transpired in the Faroe Islands was the punishment. (WB)

To determine whether the clausal expressions are used lexically or grammatically, we assume with Boye and Harder (2007, 581-585; 2012, 7-8) that lexical uses constitute the primary point of the discourse, while grammatical uses have secondary discourse status. Lexical material is therefore inherently "addressable", which can be tested for by applying recognition criteria to the syntagm in context, such as tags, really-queries and yes-no questions. In (5), there is no doubt can be naturally questioned (5a), tagged $(5 b)$, or queried (5c): 
(5a) Is there no doubt that what transpired in the Faroe Islands was the punishment?

(5b) There is no doubt that what transpired in the Faroe Islands was the punishment, is there?

(5c) There is no doubt .... Really?

By contrast, there's no doubt in (1) is secondary in the discourse in relation to the lexical material which it modifies. It is not addressable by yes/no questions, tag questions or queries:

(1a) *Is there no doubt, Peter Mandelson is a disaster?

(1b) *There's no doubt, Peter Mandelson is a disaster, is there?

(1c) *There's no doubt ... . Really?

Rather, these forms will naturally address the proposition that is the main point of the discourse, showing up the "ancillary" (Boye and Harder 2012, 19) grammatical status of there's no doubt. ${ }^{2}$

(1d) Is Peter Mandelson a disaster?

(1e) There's no doubt, Peter Mandelson is a disaster, isn't he.

(1f) ... Peter Mandelson is a disaster. Really?

The synchronic presence of lexical and grammatical layers is often taken to suggest that lexical uses came first and the constructions acquired grammatical meaning later. This is the case for the at first sight similar clausal expressions with no question. The earliest attestations contain lexical, complement-taking uses of expressions such as make question (6) and there were questions proponed (7). These lexical uses later grammaticalized into modal modifiers of propositions, after they had been routinized with negative polarity (Davidse and De Wolf 2012), e.g. (8) and (9).

(6) thei mad question to what entent thei schuld rise, [...]

'They asked to what purpose they should rise, ...' (PPCME, (a1464) Capgr.Chron. (Cmb Gg.4.12) 241)

(7) After this were there certaine questions [...] proponed, whether the king needed [...] to have any scruple at all, and if he had, what way were best to be taken to deliver him of it. (PPCEME, c1555 Roper, Life of More)

(8) Till I cried out: "You prove yourself so able, Pity! You was not Druggerman at Babel;

For had they found a linguist half so good 
I make no question but the tower had stood." (CLMETEV, 1733-34 Pope, An essay on man)

(9) there is no question but the regard to general good is much enforced by the respect to particular. (CLMETEV, 1751 Hume, An enquiry concerning the principles of morals)

However, the history of the no doubt expressions presents us with a more complex picture, which goes against certain traditional grammaticalization hypotheses. Therelit is no doubt clauses followed by a proposition in fact emerged immediately with negative polarity and modal grammatical meaning in Middle English. Intriguingly, the lexical usage of there is no doubt illustrated in (5) emerged later, in Early Modern English. This goes against the idea that grammatical uses of clauses typically result from the reanalysis of lexical uses, by which the former matrix is demoted to a modifier of the erstwhile complement (Hopper and Traugott 2003, 207-209). We will seek to account for this surprising diachrony within Boye and Harder's $(2007,2012)$ discourse approach to grammaticalization and lexicalization.

By contrast, the composite predicates have/make doubt did start off as lexical positive predicates. Negative make/have no doubt developed grammatical uses later, thus displaying a parallel history to make (no) question. However, unlike make/have no question, grammaticalized make/have no doubt developed discourse marker uses such as illustrated in (3) above. Also unlike make/have no question, make/have no doubt featured parenthetical uses, first lexical ones and later grammatical ones. To interpret the role played by these parenthetical uses in the development of discourse marker uses, we will invoke the principles of Thetical Grammar, as outlined by Kaltenböck, Heine and Kuteva (2011). They hold that (paren)theticals are governed by formal and semantic principles different from those of Sentence Grammar. Formally, theticals are not a constituent of hierarchical structure; rather, they are syntactically and prosodically independent from their anchor. They may have lexical or grammatical uses, but their functions always orient towards the situation of discourse.

The structure of the article will be as follows. In Section 2, we discuss the data on which this study is based. In Sections 3 to 5, we reconstruct the emergence and development of the various clausal patterns and adverbials in Middle English (Section 3), Early Modern English (Section 4) and Late Modern English (Section 5). In Section 6, we survey the outcome of these processes in Present-day English. In the final section, we offer theoretical reflections and conclusions. 


\section{Data}

As the noun doubt was borrowed from Old French into the English language in Middle English, with the earliest attestation $a 1225$ (OED, s.v. doubt $\mathrm{n}^{1}$, def. 1.a), it was necessary to collect diachronic data from Middle English on. The following historical corpora were consulted: the Penn-Helsinki Parsed Corpus of Middle English (PPCME2) for the period 1150-1500 (Kroch and Taylor 2000), the Penn-Helsinki Parsed Corpus of Early Modern English (PPCEME) for 1500-1710 (Kroch, Santorini, and Delfs 2004) and the extended version of the Corpus of Late Modern English texts (CLMETEV) for 1710-1920 (see De Smet 2005). Since we wanted to include all the early variation in the expressions with doubt, the queries did not specify any negative elements but merely netted all nominal hits. The queries also included all possible spellings that were attested in the Oxford English Dictionary. ${ }^{3}$ In total, the diachronic dataset for doubt consisted of 4,567 hits. Irrelevant hits such as verb forms were removed manually.

The synchronic dataset was compiled from the WordbanksOnline English corpus (1972-2005). For reasons of comparability with the diachronic data, we extracted data from written British English sources only. We took a random sample of 250 hits, obtained by the search string no doubt. This choice has the inconvenience of excluding all variation on the level of quantifiers and other pre-modifiers, but it informs us on the relative frequency of the various constructions, turning up adverbial and clausal patterns in one single query. As the general development transpiring from the diachronic data is towards less variation and entrenchment of the string no doubt, a single query that safeguarded the random character of the data seemed the preferable option.

\section{Middle English (1150-1500)}

\subsection{Clausal structures}

\subsection{1. (It/there) is no doubt}

To reconstruct the development of the modal and discourse marker uses of clausal structures with (no) doubt, the relevant patterns are those in which there/it/ $\phi$ be (no) doubt and have/make (no) doubt relate to other states-ofaffairs. ${ }^{4}$ The first relevant hit in our data, example (10), occurred in the period between 1150 and 1250. It is an existential clause, realized by the pattern without initial pronoun and with a post-verbal subject, which was the most common type of existential in Old and Early Middle English (Breivik 1983, 
278, 319; López-Couso 2006, 182; Traugott 1992, 217-219). ${ }^{5}$ As pointed out by López-Couso (2011), negative existentials in Early English in particular "lagged behind their affirmative counterparts in the adoption of the introductory subject there" $(2011,96)$. The noun doubt has its full lexical meaning, most probably that of 'fear' (OED, s.v. doubt $\mathrm{n}^{1}$, def. †3.a). In accordance with Visser's (1970, I, 19-20) analysis of Early English 'is pity' as meaning something like 'there is pity', 'people are sorrowing', nis naut swa muche dute can be assumed to mean 'there is not so much fear', 'people are not so afraid'. The prepositional phrase introduced by of indicates the events, in nominalized form, of which 'there is not so much fear'.

(10) Of pe lichte openliche bi hwam he seið alswa, Lucebit post eum semita, nis naut swa muche dute.

'Of the trivial, manifest [temptations], about which he [i.e. Job] also says: "The path will be clear after him [i.e. the Leviathan]", there is not so much fear. (PPCME, ?c1225 Ancr. (Cleo C.6) II.164) ${ }^{6}$

The subperiod 1350-1420 of Middle English saw the emergence of grammaticalized clauses with no doubt that modally qualify the proposition in their scope. They express the epistemic notion of certainty, i.e. of strong speaker commitment to the truth of the proposition. From the start, these constructions have abstract grammatical meaning, presumably derived from the 'uncertainty' sense of doubt (OED, s.v. doubt n. ${ }^{1}$, def. 1.a). Our data do not contain any bridging contexts linking them directly to lexical uses such as (10), in which not so much doubt still involved the meaning 'fear' of the noun doubt.

The example in this period whose matrix syntactically most resembles that of (10) has no doubt as post-verbal NP (11). It is most plausibly interpreted as existential as its abstract meaning of 'certainty' can be related naturally to the lexical meaning 'there was no doubt', 'people don't doubt'.

(11) And also a man sholde sorwe namely for al that evere he hath desired again the lawe of God with perfit consentynge of his resoun, for therof is no doubt, that it is deedly synne in consentynge.

'And a man should also feel sorrow especially for all that he ever has desired against the law of God with perfect approval of his reason, for of that (there) is no doubt, that it is deadly sin in approval.' (PPCME, c1405 Chaucer CT.Pars. (Elsm) 295.C2)

In (11), thereof is no doubt is not the primary point of the discourse, but the following proposition is, as shown by the addressability tests: ... it is mortal sin to approve. Really? - Is it mortal sin to approve? It is mortal sin to approve, isn't it. In other words, thereof is no doubt has ancillary, grammatical status with regard to the proposition. 
In our 1350-1420 data, there are several instances with the syntagm it is no doubt. ${ }^{7}$ It is no doubt occurs mostly in initial position (12)-(13), but there is one instance of final position (14). In (12), this creates a syntagm that looks like what is traditionally called an "extraposition" structure, while in (14) it is no doubt functions as parenthetical. In all these examples, the existential interpretation of it's no doubt continues to be the most plausible reading. As noted by Breivik (1983, 257; 1990, 228), the use of existential it as alternative of existential there was most common in Middle and Early Modern English. When Mitchell (1985, I, 625) discusses it as an early alternative of expletive pær, he illustrates this, amongst others, with the Old English example Is hit lytel tweo prt.... 'Is there little doubt that ...', thus attributing an existential reading to the older Anglo-Saxon counterpart of the extraposition constructions with it is no doubt that. As noted above, the grammatical-modal meaning of 'certainty' derives naturally from lexical existential 'there not being any doubt'. It is more difficult to conceive of 'no doubt' as a quality being attributed to a proposition $\mathrm{p}$ in a predicative relation: ? 'that $\mathrm{p}$ is no doubt'. A final argument for the existential reading is that there is no doubt actually appears as alternative of it is no doubt in examples such as (15). When existential it dropped out of use, the syntagms with it virtually disappeared after 1570 and were replaced by there is no doubt (see Sections 4 and 5).

(12) For it is no doute pat in pe song pat pe wisdom of God made, he pat techep breddes singe, ne ben fele sotile and swete notes.

'For it is no doubt that in the song which the wisdom of God made God who teaches birds to sing - there are not many subtle and sweet notes.' (PPCME, c1450(c1400) Vices \& V.(2) (Hnt HM 147) 104)

(13) And certes, pis is pe wonderful vertu of pe grete mercy of God [...]. For it is no doute, God may seye to whom hym euere lest pe same pat he seyde to pis paltyk man: 'Sone, py synnes bep forzyue pe.'

'And certainly, this is the wonderful virtue of the great mercy of God [...]. For it is no doubt, God may say to whomever he releases, the same as he said to this paralysed man: "Son, your sins are forgiven to you." (PPCME, a1450 Aelred Inst.(2) (Bod 423) 43)

(14) The especes that sourden of Pride, soothly whan they sourden of malice ymagined, avised, and forncast, or elles of usage, been deedly synnes, it is no doute.

'The types [of sin] that originate in pride, truly when they originate in imagined, devised and planned malice or else in habitual action, are deadly sins, it is no doubt.' (PPCME, c1405 Chaucer CT.Pars. (Elsm) 302.C1) 
(15) And of thise thinges ther nis no doute that thei ne ben doon ryghtfylly and ordeynly, to the profit of hem to whom we seen thise thingis betyde.

'And of these things, there is no doubt that they are done rightfully and reasonably, to the profit of them to whom we see these things happen.' (PPCME, c1450 Walton Boeth. (Cmb Gg.4.18) 453.C2)

In all cases, it/there is no doubt has grammatical meaning, assessing the proposition it modifies as 'certain'. In (12), where the proposition is structurally subordinated by that, Boye and Harder's (2007; 2012) addressability tests still show this proposition to be the main point of the discourse: the sentence does not describe an act of not doubting, but asserts that there are not many subtle and sweet notes in the song that God made. In (13) and (14), the grammatical meaning of it is no doubt is contextually supported by the repetition of similar propositions modified by modal adverbs certes and soothly.

How can the sudden emergence of (it/there) be no doubt clauses with grammatical, epistemic meaning in the period 1350-1420 be explained? To the extent that their appearance was more or less instantaneous, not gradually prepared by bridging contexts, they can be said to be the result of co-optation (p.c. Laurel Brinton), the instantaneous redefinition of a unit for grammatical use (cf. Kaltenböck et al 2011, 879) ${ }^{8}$. Moreover, the general pattern of (it/there) be no + noun- modifying a proposition in terms of grammatical meaning was already well entrenched in this period. A common instantiating construction was, for instance, (it) is no wonder, which was attested with the proposition-modifying meaning "lack of surprise" (Simon-Vandenbergen and Aijmer 2007, 37) from 850 on (Matthijs, Davidse, Van linden, Brems 2012). The co-optation of (it/there) is no doubt to extraposition and parenthetical uses may have been facilitated by such already existing constructions.

The emergence of the typical extraposition form illustrated by examples such as (12) also suggests a different view on extraposition than the traditional one, as has been implicitly recognized in some historical studies (e.g. Van linden 2012, 128-133). The traditional definition is formulated as follows in Huddleston and Pullum (2002, 1403):

In the basic version, the subject position is filled by a subordinate clause. [...] In the version with extraposition, the subject position is filled by the pronoun it and the subordinate clause appears at the end of the matrix clause [...]. Semantically, the subordinate clause stands in the same relation to the verb (or verb + predicative complement) $[\ldots]$, but syntactically the switch [...] transfers the subject properties from the subordinate clause to $i$. 
From a diachronic point of view, however, the so-called "extraposed" position of the complement clause reveals itself to be the "basic" one in that it is the first to appear and the unmarked option. If a specific structure develops a nonextraposed variant, it always comes later and is very rare. The first example with fronted complement clause of existential there is no doubt occurs only in the period $1710-1780$ in our data:

(16) That he was a lover of the muses, there is not the least doubt, as we find him patronizing the poets so warmly. (CLMETEV, 1753 Cibber, The lives of the poets of Great Britain and Ireland)

Moreover, studies going back to Old English show that the it's no $X$ that form tends to be preceded by other structures with an extraposed complement clause such as matrices without pronouns it or there, like (11) above (Van linden 2012, 128-133). Finally, extraposition structures with NPs such as no doubt and no question have existential there as their unmarked subject, rather than $i t$. This reveals that unstressed cataphoric pronouns it and there (Halliday and Hasan 1976, 101) are part of the syntax of the matrix, and contribute to its abstract semantics, such as the existential semantics of it/there is no doubt. ${ }^{9}$ Admittedly, when in Modern and Present-day English, there became the only strictly existential pronoun and the matrices became increasingly formulaic, neutralization mechanisms probably eroded the difference between the originally existential or predicative meaning of specific matrices to a certain extent. Still, the history of extraposition structures such as it/there's no doubt/question shows that it - or there - cannot be viewed purely as a placeholder of the following proposition.

\subsubsection{Have (great)/(no) doubt}

In the same period that it is no doubt emerged (1350-1420), the phrase have + doubt cropped up. It differs in two striking respects from the it + be patterns: it starts off expressing lexical meaning and it has, on its emergence, positive polarity. ${ }^{10}$ All examples in this period instance the schema of a "composite predicate", viz. light verb followed by deverbal noun (Brinton and Akimoto 1999). At this stage of English, have doubt meant 'to fear' (OED, s.v. doubt, $\mathrm{n}^{1}$, def. 3.a), as is very clear in (17) and (20), in whose contexts near-synonyms was adrede and drede are used. It appears most often without complement, as in (17), but it is also attested with a prepositional phrase (18), and in the final subperiod of Middle English, 1420-1500, with a clausal complement (19).

(17) The Quene Gunnore pat was Kyng Arthures wif, pat po soiournede at zork and herde pat Mordrede was fledde pens pat he was, and mizt 
nou3t endure azeyues Kyng Arthure, she was sore adrade, and hade grete doute, $[\ldots]$.

'Queen Guinevere, who was King Arthur's wife and who stayed in York at that time, and heard that Mordred had fled to where he was, and might not endure against King Arthur, she was bitterly afraid, and had great fear, ...' (PPCME, c1400 Brut-1333 (Rwl B.171) 89)

(18) Bot sho sal haue dute of pat vre lauerd saide wyd pe prophete til pe hirdis of haly kirke: "Quod crassum videbatis. Pat fat ere, sal ye ta, pat ere febyl, let ga."

'But she [i.e. the abbess] shall have fear about what our lord said with the prophet to the shepherds of the holy church: "You were looking at what is thick. What is fat, you shall take, what is weak, let it go." (PPCME, a1425 Ben.Rule(1) (Lnsd 378) 22)

(19) and than he seyde, "Sir Gawayne, Gawayne! Ye have sette me in grete sorow, for I have grete doute that my trew felyshyp shall never mete here more agayne."

'and then he said: "Sir Gawain, Gawain! You have set me in great sorrow, for I have great fear that my true fellowship will nevermore meet here again." (PPCME, (a1470) Malory Wks. (Win-C) 635)

In 1420-1500, have doubt started occurring with negative polarity, mainly as an imperative on its own, as in (20) and (21). As noted by SimonVandenbergen $(2007,29)$, we see the exploitation here of "the rhetorical potential of the expression". The imperatives are lexical uses, but they activate the communicative relation between the speaker and the hearer, with the speaker telling the addressee that s/he 'need not fear'. However, they qualify as structurally detached, thetical units, whose typical discourse-oriented functionality they have, expressing "particulars of speaker-hearer relations" (Kaltenböck et al. 2011, 866). From the perspective of Thetical Grammar, these interactional imperatives can be singled out as an important step in the development towards grammaticalized discourse markers (see Sections 5.1 and 7).

(20) \& perfor, dowtyr, drede pe neuyr, for alle pe gret behestys pat I haue behite to pe $[\ldots]$ xal euer be trewe \& trewly fulfilled whan tyme comyth. Haue no dowt per-of.

'And therefore, daughter, never fear yourself, for all the great promises that I have made to you ... will ever be true and truly fulfilled when time comes. Have no fear thereof.' (PPCME, (a1438) MKempe A (Add 61823) 91) 
"But, sir," seyde the lady, "as thou arte called the worshypfullyest knight of the worlde, I require the [...], kepe me and save me, for whatsomever he sey he woll sle me, for he is withoute mercy." "Have ye no doute: hit shalle nat lye in his power."

"But sir," said the lady, "as you are the most worshipful knight of the world, I require you ..., keep me and save me, for whatsoever he says, he will slay me, for he is without mercy." "Don't you have any fear; it will not lie in his power."' (PPCME, (a1470) Malory Wks. (Win-C) 207)

\subsection{Adverbial}

The earliest hits in our data of the adverbial no doubt are from the period $1350-1450$, i.e. the period in which it is no doubt and have doubt emerged. ${ }^{11}$ All adverbials in Middle English occur in initial position. From the start, the adverbial may express either certainty (22) or less than full certainty (23), depending on contextual elements, such as the modal verb moun 'may' in (23), which points to possibility. As disjuncts, i.e. adverbials that are not part of clause grammar but whose meaning typically has scope over the whole clause (Quirk et al. 1985, 618-628; Brinton 2008, 131), they all belong to the domain of Thetical Grammar and have its discourse-oriented functionality.

(22) but oppresson per seruauntis pat owen hem but a lytul dette [...] And opre seruauntis of God, bope in pis lif and pe topre, tellen to God pis felnesse and preyen hym of veniaunce. No dowte God is wrop at pis.

'But they oppress their servants that owe them but a little debt. ... and other servants of God, both in this life and in the other, tell this perception to God and pray to him for vengeance. No doubt God is angry at this.' (PPCME, ?a1425 Wycl.Serm. (Add 40672) 311)

(23) And where I haue translatid as opinli or opinliere in English as in Latyn, late wise men deme, that knowen wel bothe langagis, and knowen wel the sentence of holi scripture. And wher I haue do thus, or nay, ne doute, thei that kunne wel the sentence of holi writ and English togidere, $[\ldots]$ moun make the bible as trewe ans as opin, 3ea, and opinliere in English than it is in Latyn.

'And where I have translated as clearly or more clearly in English than in Latin, let wise men judge, who know both languages well, and know the contents of the holy scripture well. And where I have done thus, or no, no doubt, they who know well the contents of the holy scripture and English also, ... can make the holy bible as true and as clear, yea, and 
more clear in English than it is in Latin.' (PPCME, a1450(a1387) Purvey CGosp.Prol.Mat. (Hrl 6333) I, 58)

Simon-Vandenbergen $(2007,32)$ notes that the development of the noun phrase no doubt into an adverbial, given the chronology of its emergence, may be plausibly viewed as "a shortened version of the clausal construction". Speakers may have felt that the modification of propositions could be equally realized by reduced versions of clausal structures (Simon-Vandenbergen 2007, 14). In any case, a crucial factor in the emergence of the adverbial use of no doubt was the fact that speakers at that time could extract the schematic template "negative element + modal noun' from extant adverbials. As pointed out by De Wolf (2010, 27), speakers could refer not just to a "meso-constructional" schema (Traugott 2008), but to a "meso-constructional paradigm", which sanctioned not only no doubt, but also without doubt, (24), and, a bit later, out of doubt (25). In fact, one of the earliest micro-constructions of this adverbial paradigm was butan tweon 'outside of/without doubt', which was already present in Old English, as shown by a number of examples in the York-Toronto-Helsinki Parsed Corpus of Old English Prose (Taylor et al. 2003). ${ }^{12}$

(24) Cry mercy, and aske anely saluacyon by pe vertu of his percyouse passion meekly and tristely, and with-owtten dowte pou sall haf it, $[\ldots]$.

'Cry out mercy, and humbly and faithfully ask only salvation by the virtue of his revered passion, and without doubt, you will have it, ... .' (PPCME, c1440(a1349) Rolle (Thrn) 44)

(25) But I feare it will ende with a mocke for pastance. I bring hir a ring, with a token in a cloute. And by all gesse, this same is hir house out of doute. I know it nowe perfect. I am in my right way. (PPCEME, 1552-53 Udall, Roister Doister)

By way of conclusion, Table 1 gives the quantitative instantiation of all the construction types that were discussed in this section on Middle English. Because of the very small absolute numbers, no relative frequencies are given, as no firm conclusions can be drawn from them. Bold face indicates the use, lexical or grammatical, of a structure type that predominates in a given period.

Table 1. Lexical and grammatical uses of structure types with (no) doubt in Middle English

\begin{tabular}{lcccccccc}
\hline $\begin{array}{l}\text { Structure } \\
\text { Type }\end{array}$ & $1150-1250$ & $1250-1350$ & $1350-1420$ & \multicolumn{1}{c}{$1420-1500$} \\
\hline Use & lex & gram & lex & gram & lex & gram & lex & gram \\
\hline
\end{tabular}




\begin{tabular}{lcccccccc}
\hline $\begin{array}{l}\text { Adverbial } \\
\text { no doubt } \\
\text { there is no }\end{array}$ & 0 & 0 & 0 & 0 & 0 & $\mathbf{3}$ & 0 & 1 \\
$\begin{array}{l}\text { doubt } \\
\text { it is no }\end{array}$ & 0 & 0 & 0 & 0 & 0 & $\mathbf{2}$ & 0 & 0 \\
$\begin{array}{l}\text { doubt } \\
\text { is no doubt }\end{array}$ & 0 & 0 & 0 & 0 & 0 & $\mathbf{3}$ & 0 & $\mathbf{2}$ \\
$\begin{array}{l}\text { have (no) } \\
\text { doubt }\end{array}$ & 0 & 0 & 0 & 0 & 0 & $\mathbf{2}$ & 0 & 0 \\
\hline Total & 1 & 0 & 0 & $\mathbf{5}$ & 0 & $\mathbf{5}$ & 0 \\
\hline
\end{tabular}

\section{Early Modern English (1500-1710)}

By the end of Middle English, all the basic construction types that expressed or later came to express - modal meaning had appeared. Table 2 gives a quantitative survey of the further development of these constructions in Early Modern English. The table shows that existentials with it virtually disappeared after 1570, and that from that same moment on the adverbials surpassed the clausal structures in number. Within the clausal structures, the there existentials were the most common and besides have (no) doubt, the composite predicate make (no) doubt emerged. The relative frequencies of occurrence are given for the lexical and grammatical uses of all the structure types within each subperiod, and bold face indicates the predominant use of a structure. Table 3 shows the positions occupied by the adverbials and the grammaticalized clauses. The adverbial no doubt developed much more positional flexibility than it had in Middle English, occurring clause initially (48\%), medially (37\%) and finally (15\%). There/it is no doubt continued to favour initial position over final position, while grammaticalized uses of I have no doubt emerged in initial position.

Table 2 Lexical and grammatical uses of structure types with (no) doubt in Early Modern English

\begin{tabular}{lcccccc}
\hline \multirow{2}{*}{\begin{tabular}{l} 
Structure \\
Type \\
\cline { 2 - 7 } Use
\end{tabular}} & \multicolumn{2}{c}{$1500-1570$} & \multicolumn{2}{c}{$1570-1640$} & \multicolumn{2}{c}{$1640-1710$} \\
\hline $\begin{array}{l}\text { Adverbial } \\
\text { no doubt }\end{array}$ & $0(0 \%)$ & $\mathbf{2}(\mathbf{1 1 \%})$ & $0(0 \%)$ & $\mathbf{1 8}(\mathbf{6 4 . 5 \%})$ & $0(0 \%)$ & $\mathbf{7}(\mathbf{7 0 \%})$ \\
$\begin{array}{l}\text { there is } \\
\text { no doubt }\end{array}$ & $1(5.5 \%$ & $\mathbf{7 ( 3 9 \% )}$ & $0(0 \%)$ & $\mathbf{6}(\mathbf{2 1 . 5 \% )}$ & $1(10 \%)$ & $1(10 \%)$ \\
it is no & $1(5.5 \%)$ & $\mathbf{4 ( 2 2 . 5 \% )}$ & $0(0 \%)$ & $0(0 \%)$ & $0(0 \%)$ & $0(0 \%)$ \\
\hline
\end{tabular}


14 Kristin Davidse, Simon De Wolf, and An Van linden

\begin{tabular}{|c|c|c|c|c|c|c|}
\hline $\begin{array}{l}\text { doubt } \\
\text { have (no) } \\
\text { doubt }\end{array}$ & $1(5.5 \%)$ & $0(0 \%)$ & $1(3.5 \%)$ & $1(3.5 \%)$ & $0(0 \%)$ & $0(0 \%)$ \\
\hline $\begin{array}{l}\text { make (no) } \\
\text { doubt }\end{array}$ & $2(11 \%)$ & $0(0 \%)$ & $2(7 \%)$ & $0(0 \%)$ & $1(10 \%)$ & $0(0 \%)$ \\
\hline Total & \multicolumn{2}{|c|}{$18(100 \%)$} & \multicolumn{2}{|c|}{$28(100 \%)$} & \multicolumn{2}{|c|}{$10(100 \%)$} \\
\hline
\end{tabular}

Table 3. Position of grammatical uses of structure types with no doubt in Early Modern English

\begin{tabular}{lcccccc}
\hline Position & \multicolumn{2}{c}{ Adverbial no doubt } & \multicolumn{2}{c}{ there/it is no doubt } & \multicolumn{2}{c}{ I have no doubt } \\
& $\mathrm{n}$ & $\%$ & $\mathrm{n}$ & $\%$ & $\mathrm{n}$ & $\%$ \\
\cline { 2 - 7 } Initial & 13 & $48 \%$ & 16 & $89 \%$ & 1 & $100 \%$ \\
Medial & 10 & $37 \%$ & 0 & $0 \%$ & 0 & $0 \%$ \\
Final & 4 & $15 \%$ & 2 & $11 \%$ & 0 & $0 \%$ \\
\hline Total & 27 & $100 \%$ & 18 & $100 \%$ & 1 & $100 \%$ \\
\hline
\end{tabular}

\subsection{Clausal structures}

\subsubsection{Make/have (no) doubt}

The most noticeable development in Early Modern English is the appearance of a new composite predicate, make a/much doubt, which means 'to doubt' (OED, s.v. doubt n. ${ }^{1}$, def. 4a). The first examples are positively oriented, e.g. (26), and the two hits in the period 1500-1570 are complemented by prepositional phrases.

(26) Every whole thinge is equall to all his partes taken together. It shall be mete to expresse both with one example, for of thys last sentence many men at the first hearing do make a doubt. (PPCEME, 1551 Record, Geometry)

Later on, in the period 1570-1640, the expression started to occur in negative contexts with the meaning 'not be uncertain', 'be certain', e.g. (27). Interestingly, (27) shows an interactional use of the imperative that resembles the imperative have no doubt examples (20) and (21) in Middle English, with the speaker trying to convince the addressees that they need not be uncertain. In this same period, I have no doubt came to be used with grammatical, modal meaning, as in (28), a development that was followed by I make no doubt only in Late Modern English. 
But as for this rebellion, [...], it contains in it many Branches of Treason, which are and will be directly proved, which being found to be so, my Lords, who are their Peers, are to find them Guilty. Hereof need to be made no doubt,[...]. (PPCEME, 1600 Essex State Trials)

Attend to those things which I shall relate, and I have no doubt, but I shall very much accomplish your desire in this. (PPCEME, 1627 Brinsley, Ludus literarius)

These new uses resulted from the reanalysis of the earlier complementation structure with lexical complement-taking predicate into a secondary, grammatical modifier.

\subsubsection{There/it is no doubt}

The existential structures continued to be used with the epistemic meaning they emerged with in Middle English: in (29) there is no doubt is not the consequence of Euripides' words but merely expresses the speaker's commitment to the primary point, viz. that not having children can only coincidentally lead to happiness.

(29) [...] I do allowe the sentens of my dyscyple Eurypides that sayde, he is happye by mischaunce that hath no children. Therefore ther is no doughte but that these ways, be certayne byways vnto felicitie or blessedness (PPCEME, 1556 Colville, Boethius' Consolation)

However, in Early Modern English we also find two examples, as shown in Table 2 above, in which a matrix with negation + doubt has lexical meaning, as in (30), where doughteth in the following discourse indicates that the point of the previous question Is it any doubt is to ascertain whether any doubt exists. Addressability tests also show that Is it any doubt has primary discourse status: It is not any doubt that the good folk are mighty. Really? It is not any doubt that the good folk are mighty, is it?

(30) Then when that both good and euyll folke desyreth good, yf the good folke obtayneth the good and the euil folke do not, Is it nowe anye doughte but that the good folke be myghty, and the euill folke vnmyghty? I saye whoseouer doughteth thys, can not consyder the nature of things, nor the consequence of reson. (PPCEME, 1556 Colville, Boethius' Consolation)

As existential clauses with no doubt first emerged with epistemic meaning, we have to view examples such as (30) as instancing the directionality from grammatical to lexical meaning. More precisely, grammaticalization is 
followed by lexicalization, because the outcome is an idiomatic phrase conveying the verbal meaning 'not doubt'. Lehmann (2002) has pointed out that lexicalization often precedes and enables grammaticalization by routinizing a unit as one chunk. It is actually not so surprising that the reverse process also occurs: a unit routinized in a grammaticalization process may come to be used as a semi-fixed lexicalized chunk. Lexicosemantically, this can be explained by Hopper's (1991) principle of "persistence": even with fully grammaticalized comment clauses, language users still have access to the original lexical meaning of its components and can reactivate it (p.c. Laurel Brinton). Structurally, this lexical activation can be explained by the "fact that CTPs [complement-taking predicates] and CTP clauses are involved in complex clauses" (Boye and Harder 2007, 588), which gives them an inherent flexibility to endow the structural matrix with either secondary or primary discourse status.

\subsection{Adverbial}

The adverbial pattern no doubt also manifested some syntactic and semantic changes in Early Modern English. What is most striking syntactically is the adverbial's increased positional flexibility, which by 1570 included medial (31) and final (33) position. Furthermore, a more elaborate variant of the adverbial emerged, containing phoric reference of it to the proposition being modified (31), which seems to grant the modal qualification extra emphasis.

(31) He was a stoute stomaked child, a biwalker, of an ambitious mynde, he wold not consente to hys fathers frendes, but gate him a charet, and men to runne before it, and dyuerse other adherents to helpe hym forwarde, wordelye wise men, such as had bene before of hys fathers counsayle, $[\ldots]$ and some no doute of it, came of good wil thynkynge no harme, for they woulde not thynke that he did it wythoute hys fathers wyll. (PPCEME, 1549 Latimer, Sermon on the ploughers)

A possible explanation for this development can be sought in the semantic indeterminacy that characterized the adverbial from the start (see Section 3.2). No doubt was increasingly used in contexts that suggest a meaning of less than full certainty, as in (32) where the modal may hints at possibility. The longer, more emphatic adverbial form was probably a counterdevelopment to the short form's epistemic bleaching.

(32) And no doubt there may infinit examples be brought. (PPCEME, 1593 Gifford, Witches and witchcraftes) 
In spite of the general tendency towards weaker epistemic meanings, no doubt still occurred with a meaning close to full certainty. One such environment is formed by concessive discourse contexts such as (33), which have persisted until the present day. The proposition associated with no doubt is first posited as being true, only to be backgrounded straight away by a second, conflicting argument which is perceived as more important in the speaker's argumentation. The clause containing no doubt has a rhetorically concessive function, in that it 'pre-empts' a possible objection (Martin 1992, 223). Simon-Vandenbergen (2007) observes that no doubt in such concessive contexts is "closer to certainly or of course than to probably" $(2007,16)$.

(33) That is most true no doubt, which you speake. I doe not for any part knowe how to gainsay any point thereof. (PPCEME, 1593 Gifford, Witches and witchcraftes)

\section{Late Modern English (1710-1920)}

Quantitatively, the Late Modern English data continue the trends observed in the final stages of Early Modern English. As shown in Table 4, the adverbs account for the larger half of all attestations. Within the grammaticalized clausal structures I have no doubt and there is no doubt constitute roughly comparable proportions, except in the period 1780-1850, when I have no doubt peaked. Grammaticalized I make no doubt had peaked in the period 17101780. The alternative forms feel (no) doubt and entertain (no) doubt that appeared in Late Modern English never became more than minor variants. As Table 5 shows, adverbial no doubt came to favour medial position $(56 \%)$ over initial (31.5\%) and final position (12.5\%). There is no doubt kept its distribution which had always been strongly skewed towards initial $(84.5 \%)$ over final position (14.5\%). By contrast, grammaticalized I have/make no doubt started occurring in medial position (14\%), in addition to their initial (76\%) - final (10\%) skew. Qualitatively, the most important development is the emergence of discourse marker uses of the adverbials and of I have/make no doubt, which, within a Thetical Grammar perspective, can be related to their positional flexibility and discourse-functional characteristics.

Table 4. Lexical and grammatical uses of structure types with (no) doubt in Late Modern English

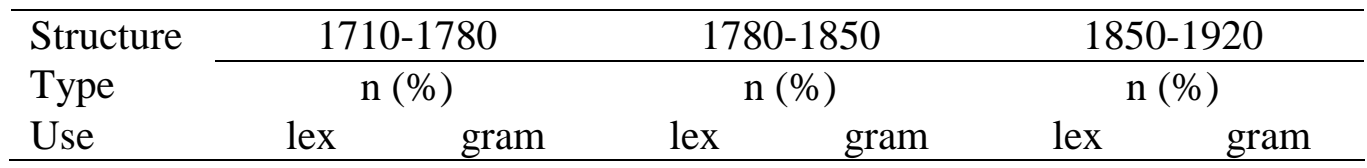


18 Kristin Davidse, Simon De Wolf, and An Van linden

\begin{tabular}{|c|c|c|c|c|c|c|}
\hline $\begin{array}{l}\text { Adverbial } \\
\text { no doubt }\end{array}$ & $0(0 \%)$ & $\begin{array}{c}151 \\
(55.5 \%)\end{array}$ & $0(0 \%)$ & $\begin{array}{c}248 \\
(42 \%)\end{array}$ & $0(0 \%)$ & $\begin{array}{c}616 \\
(64 \%)\end{array}$ \\
\hline $\begin{array}{l}\text { there is } \\
\text { no doubt }\end{array}$ & $8(3 \%)$ & $21(7.5 \%)$ & $28(5 \%)$ & $76(13 \%)$ & $66(7 \%)$ & $\begin{array}{c}115 \\
(12 \%)\end{array}$ \\
\hline $\begin{array}{l}\text { it is no } \\
\text { doubt }\end{array}$ & $1(0.33 \%)$ & $0(0 \%)$ & $2(0.33 \%)$ & $0(0 \%)$ & $0(0 \%)$ & $0(0 \%)$ \\
\hline $\begin{array}{l}\text { have (no) } \\
\text { doubt }\end{array}$ & $16(6 \%)$ & $15(5.5 \%)$ & $53(8 \%)$ & $\begin{array}{c}169 \\
(28 \%)\end{array}$ & $52(5.4 \%)$ & $98(10 \%)$ \\
\hline $\begin{array}{l}\text { make (no) } \\
\text { doubt }\end{array}$ & $8(3 \%)$ & $49(18 \%)$ & $2(0.33 \%)$ & $6(1 \%)$ & $0(0 \%)$ & $7(0.7 \%)$ \\
\hline $\begin{array}{l}\text { feel no } \\
\text { doubt }\end{array}$ & $0(0 \%)$ & $0(0 \%)$ & $2(0.33 \%)$ & $3(0.66 \%)$ & $2(0.2 \%)$ & $3(0.3 \%)$ \\
\hline $\begin{array}{l}\text { entertain } \\
\text { no doubt }\end{array}$ & $1(0.33 \%)$ & $1(0.33 \%)$ & $1(0.17 \%)$ & $1(0.17 \%)$ & $4(0.4 \%)$ & $0(0 \%)$ \\
\hline Total & 271 & $0 \%)$ & 591 & $00 \%)$ & 962 & $00 \%)$ \\
\hline
\end{tabular}

Table 5. Position of grammatical uses of structure types with no doubt in Late Modern English

\begin{tabular}{lcccccc}
\hline Position & \multicolumn{2}{c}{ Adverbial no doubt } & \multicolumn{2}{c}{ there/it is no doubt } & \multicolumn{2}{c}{ I have no doubt } \\
& $\mathrm{n}$ & $\%$ & $\mathrm{n}$ & $\%$ & $\mathrm{n}$ & $\%$ \\
\cline { 2 - 7 } Initial & 320 & $31.5 \%$ & 181 & 85.5 & 268 & $76 \%$ \\
Medial & 570 & $56 \%$ & 1 & $0.5 \%$ & 49 & $14 \%$ \\
Final & 125 & $12.5 \%$ & 30 & $14 \%$ & 35 & $10 \%$ \\
\hline Total & 1015 & $100 \%$ & 212 & $100 \%$ & 352 & $100 \%$ \\
\hline
\end{tabular}

5.1. Clausal structures

\subsubsection{Make/have/feel (no) doubt}

In Late Modern English, make doubt displayed a boom-and-bust cycle, becoming the most popular matrix between 1710 and 1780, but decreasing quickly in frequency afterwards. Occurring frequently in final position (34), and occasionally in medial position (35), its thetical status increased in the period of its popularity. It was still used lexically, as in (34) where the idiom is contextually contrasted with I very much doubt, but it occurred more often with grammatical, epistemic meaning, as in (35) and (36). In its grammatical uses, it often displayed, unlike the existential clausal structures but very much like the adverbials, semantic bleaching of the certainty meaning, expressing probability or a personal conviction as in (35), or possibility as in (36), where it can be paraphrased as I suppose (Simon-Vandenbergen 2007, 27-29). 
That Caesar was murdered by twenty-three conspirators, I make no doubt: but I very much doubt that their love of liberty, and of their country, was their sole, or even principal motive; [...]. (CLMETEV, 1748 Chesterfield, Letters to his son)

(35) [...] what fancied importance sate perched upon my quill while I was writing. The whole learned world, I made no doubt ${ }^{13}$, would rise to oppose my systems; but then I was prepared to oppose the whole learned world. (CLMETEV, 1766 Goldsmith, The vicar of Wakefield)

(36) $[\ldots]$ he [the prisoner] is resolved to take the advice of counsel in what manner to proceed for his immediate enlargement. I make no doubt, but that in a day or two this troublesome business may be discussed; ... (CLMETEV, 1751 Smollett, The adventures of Peregrine Pickle)

It is these weaker meanings that allowed the expression to be used in contexts that encourage the involvement of an addressee, as in (37). The combination of a marker of supposition with a proposition that concerns the addressee creates a pragmatic function that means as much as 'can you confirm my supposition?'.

\footnotetext{
"Why, aye my son," cried I, "you left me but poor, and poor I find you are come back; and yet I make no doubt you have seen a great deal of the world."

"Yes, Sir," replied my son, "but travelling after fortune, is not the way to secure her; [...]" (CLMETEV, 1766 Goldsmith, The vicar of Wakefield)
}

In example (38), the expression in itself allows one to infer that the speaker invites a confirmation (without explicitly addressing the hearer) about all the things that have to be got home.

$$
\begin{aligned}
& \text { "[...] Such weather must be terrible bad for a young chap just come } \\
& \text { from a fiery nation like Indy; hey, naibour Cannister?" } \\
& \text { "Trew, trew. And about getting home his traps? Boxes, monstrous } \\
& \text { bales, and noble packages of foreign description, I make no doubt?" } \\
& \text { 'Hardly all that,' said Stephen laughing. (CLMETEV, } 1873 \text { Hardy, A } \\
& \text { pair of blue eyes) }
\end{aligned}
$$

As the basic function of such examples is to convey to the addressee that his or her input is desirable or required, ${ }^{14}$ they qualify as discourse markers. They "signal an aspect of the speaker's rhetorical stance toward what he or she is saying, or toward the addressee's role in the discourse situation" (Traugott and Dasher 2002, 152). The instances of I make no doubt in (37) and (38) comply with this definition: they convey speaker stance in that they indicate that the 
speaker is not entirely sure about his or her suppositions, and they involve the hearer in the discourse situation by inviting him or her to react.

The evolution of have no doubt very closely mirrors the developments of make no doubt. Extending its range of positions to medial (39) and final position (40), it regularly appeared as a parenthetical comment. Semantically, most of the have no doubt examples convey epistemic meaning, which is often weakened, as illustrated by (41), in which the speaker has not actually seen what he is talking about. Possible paraphrases include I suppose (39) and I am sure, but in the weaker sense of 'I have an inner conviction that I cannot prove', as in (40).

(39) They would be selected at the outset from the Army, and that on the ground of their possessing certain capabilities for the position [...] . Ultimately the Officers, we have no doubt, would be [...] men and women raised up from the Colonists themselves, [...] (CLMETEV, 1890 Booth, In darkest England and the way out)

(40) Though he seldom before had revealed his state of mind, even by looks, it was his habitual mood, I had no doubt. (CLMETEV, 1847 Brontë, Wuthering Heights)

(41) I did not see the head but have little doubt it was genuine. (CLMETEV, 1912 Butler, Note-books)

Examples such as (42), in which the addressee is encouraged to make a reply, come close to the status of discourse markers.

\footnotetext{
"Very true, dear Madam," said Emanuel, with a courteous inclination of the head. "I have no doubt this big fellow here gives you no end of trouble to keep in order."

"Ah! No one knows what it is keeping house for a great scholar like that, dear sir," said Frau Scherer, [...] . (CLMETEV, 1885 Blind, Tarantella)
}

As was the case with make doubt, there are also instances in which the expression itself signals this meaning as a fully-fledged discourse marker. An example is (43), in which the interlocutor reacts, even though s/he is not explicitly addressed, which shows that the implication of the addressee is encoded in I have no doubt proper, without depending on an overtly interactional context.

"My father is a man who seldom gives way to any elation of mind."

"Ah, indeed! A philosopher, I have no doubt, like his son." 
"I have no claims to the title of philosopher, although I have had the advantage of studying in the school of Mrs. Felix Lorraine." (CLMETEV, 1826 Disraeli, Vivian Grey)

Another discourse marker use of I have no doubt conveys interpersonal stance by twisting the predictability based on earlier experiences shared between speaker and hearer into irony (Simon-Vandenbergen and Aijmer 2007, 301), as in (44).

(44) But Swithin hearing the name Irene, looked severely at Euphemia, who, it is true, never did look well in a dress, [...] and said: "Dressed like a lady, I've no doubt. It's a pleasure to see her." (CLMETEV, 1906 Galsworthy, The man of property)

The evolutions of have no doubt and make no doubt traced so far are very much alike. However, have no doubt acquired a wider range of functions. It could, for instance, appear as a response, signalling full agreement, as in (45), where, as with the adverb in (31), the more elaborate form comes with a more emphatic degree of agreement.

"[...] The table cloth was laid under the table, instead of upon it: we sat round it on the floor: and I believe we really enjoyed that extremely uncomfortable kind of dinner more than we ever did the orthodox arrangement!"

"I've no doubt of it," Lady Muriel replied. (CLMETEV, 1889 Carroll, Sylvie and Bruno)

In Late Modern English, other multi-word predicates with similar semantics to make/have doubt were marginally present, such as entertain no doubt and, particularly, feel no doubt. The latter is not attested at all in the corpus before 1850, yet it immediately appeared both sentence-initially (48) and sentence-finally (46)-(47). It is attested both with lexical meaning ('not doubt') licensing a complement clause (46) and with grammatical epistemic meaning (47)-(48). However, have doubt and make doubt first occurred as positive lexical composite predicates, meaning 'fear' and 'doubt', and specialized only later for negative contexts, in which they acquired grammatical meaning. The fact that feel no doubt skipped this gradual development suggests that it immediately aligned with the whole set of constructions in which make/have no doubt were used. Speakers recognized that the expression conformed to the example set by make/have no doubt and immediately made use of it in much the same way. Feel no doubt hence adopted both its meanings and its distributional pattern through analogization 
with make/have no doubt (see De Smet 2012 on semantic, formal and distributional analogization).

(46) On the first opportunity Widdowson took like refuge from the rain [...]. He alighted not far from Mrs. Conisbee's house. That Monica had come hither he felt no doubt, but he would presently make sure of it. (CLMETEV, 1893 Gissing, The odd woman)

(47) "We've been there just twenty minutes," he said, "and I've done nothing but listen to you and Lady Muriel talking: and yet, somehow, I feel exactly as if I had been talking with her for an hour at least!"

And so he had been, I felt no doubt: only, as the time had been put back to the beginning of the tete-a-tete he referred to, the whole of it had passed into oblivion, if not into nothingness! (CLMETEV, 1889 Carroll, Sylvie and Bruno)

(48) "And all that strange adventure," I thought, "has occupied the space of a single comma in Lady Muriel's speech! A single comma, for which grammarians tell us to 'count one'!" (I felt no doubt that the Professor had kindly put back the time for me, to the exact point at which I had gone to sleep.) (CLMETEV, 1889 Carroll, Sylvie and Bruno)

\subsubsection{There is no doubt}

The existentials present a different development from I make/have no doubt: they did not shift towards a weaker degree of epistemic certainty or use as discourse markers, as observed by Simon-Vandenbergen (2007, 23). She (2007, 24ff.) suggests that this is due to the fact that they have an impersonal subject, viz. there. This may have prevented the expression from being used in contexts that allow a reading as a personal supposition - since there is no subject to which the conjecture can be ascribed - or as a discourse marker - as the speaker is not explicitly present to involve the addressee in the communication. There is no doubt continued to convey a high degree of certainty, as suggested by the fact that it - more than the other clausal structures - occurred in concessive contexts such as (49), which first stresses the truth of the proposition about the slave trade's long subsistence, but then discards this as an argument for its continuance. The existential was also used to signal strong commitment to a hypothetical proposition (50).

(49) Surely their lordships could never consider such a traffic to be consistent with humanity or justice. [...] That the trade had long subsisted there was no doubt, but this was no argument for its 
continuance. (CLMETEV, 1839 Clarkson, The history of the abolition of the African slave-trade)

(50) Five additional balloons at that time in readiness were never required for the risky service for which they were designed. There can be little doubt that had the siege continued a more elaborate use of balloons would have been developed. (CLMETEV, 1902 Bacon, The dominion of the air)

The existential construction displayed the least positional flexibility of the three: it occurred almost never in medial position, and its restricted occurrence following the proposition was mostly in concessive contexts such as (49).

\subsection{Adverbial}

In Late Modern English, no doubt continued to be used as an epistemic marker, expressing both certainty, as in (51), where it modifies a proposition qualified also by necessarily, and probability, as in (52), where the speaker's less than full certainty is also reflected by expressions such as one cannot but suspect. The larger portion of adverbial uses either neutralized the distinction between certainty and probability, or clearly conveyed less than full certainty.

(51) The first of these causes is no doubt necessarily connected with the diminution of the value of the precious metals; but the second is not. (CLMETEV, 1766 Smith, An inquiry into the nature and causes of the wealth of nations)

(52) A good many of the Adventure's people were ill with scurvy, and Cook is much puzzled to know the reason why they were attacked while his own crew were free. He puts it down to the greater trouble he had taken to make all his men use wild celery and other herbs in New Zealand, and no doubt this had its effect; but one cannot but suspect that the constant care on his part to keep the ship clean and sweet below had much to do with it. (CLMETEV, 1768-71 Cook, Captain Cook's journal during the first voyage round the world)

Importantly, the adverbial also developed discourse marker uses (54)(56), and it did so from the first period of Late Modern English, 1710-1780, on, whereas the first discourse marker uses of I have no doubt and I make no doubt appeared only from 1780-1850 on (De Wolf 2010, 42). The adverbial thus led the way, and we propose that this is due to the great positional flexibility it acquired in Late Modern English (Table 5), certainly in comparison with the clausal structures, but also in comparison with its own distribution in Early Modern English (Table 3). The medial position of no 
doubt came to predominate (by 56\%), which entailed that it could be inserted almost anywhere in a sentence. In some instances, it no longer relates to the entire proposition but qualifies a very precise element of it. This reduction of scope most likely contributed to the development of discourse marker characteristics, since it drew the adverb away from the propositional level, and permitted it to relate to discourse-oriented units, such as the focusing adverbial in part in $(53)^{15}$. The routinization of no doubt in medial position seems to have been conducive to ironic uses, which often interrupt a clause, e.g. (54). In parenthetical initial and final position, no doubt can convey interactional meanings. In (55), clause-initial no doubt expresses the speaker's apparent agreement, but in combination with an exaggerated explanation of the reason why the speaker agrees with the addressee it also has the opposite effect, creating the ironic undertone that Bianca is not discreet at all. In (56) clausefinal no doubt challenges the addressee to confirm the speaker's unfavourable interpretation of the addressee's previous utterance. Examples (55) and (56) illustrate that the interactional uses of no doubt also often convey interpersonal stance such as irony and sarcasm.

(53) She [Mrs. Hannah More] is, indisputably, the first literary female I ever met with. In part, no doubt, because she is a Christian. (CLMETEV, 1847 Cottle, Reminiscences of Samuel Taylor Coleridge and Robert Southey)

(54) $[\ldots]$ yet he had recourse to the mean expedient of writing obscenity, and favouring the cause of vice, by which he no doubt recommended himself to the rakes about town. (CLMETEV, 1753 Cibber, The lives of the poets of Great Britain and Ireland)

(55) "It is not fit for me to argue with your Highness," replied Bianca; "but perhaps the questions I should have put to him would have been more to the purpose than those you have been pleased to ask him."

"Oh! No doubt," said Matilda; "you are a very discreet personage! May I know what YOU would have asked him?" (CLMETEV, 1764 Walpole, The castle of Otranto)

(56) "Well, I'm sorry for it," replied he, with more of sulkiness than contrition: "what more would you have?"

"You are sorry that I saw you, no doubt," I answered, coldly.

"If you had not seen me," he muttered, fixing his eyes on the carpet, "it would have done no harm." (CLMETEV, 1848 Brontë, The tenant of Wildfell Hall) 


\section{Synchronic situation}

In Present-day English, the adverbial retains the general predominance it had established in Modern English (Table 6). However, in comparison with the last stage of Late Modern English (see Table 4), the adverbials have dropped from $64 \%$ to $48 \%$ and the clausal structures have gone up - have no doubt from $10 \%$ to $15.7 \%$, and there is no doubt from $12 \%$ to $36.7 \%$. The figures in Table 7 show that the adverbials keep the strong positional flexibility they acquired in Late Modern English, favouring medial position most. There is no doubt occurs mainly in initial position, with final position as marked alternative, as it has done since its emergence, but I have no doubt has lost the option of medial position which it had acquired in Late Modern English.

Table 6. Lexical and grammatical uses of structure types with (no) doubt in Present-day English

\begin{tabular}{lcc}
\hline Structure Type & \multicolumn{2}{c}{ Present-day English } \\
\cline { 2 - 3 } Use & lexical & $\mathrm{n}(\%)$ \\
\hline Adverbial no doubt & $0(0 \%)$ & grammatical \\
there is no doubt & $19(7.66 \%)$ & $73(47.66 \%)$ \\
have no doubt & $9(3.66 \%)$ & $30(12 \%)$ \\
\hline Total & \multicolumn{3}{c}{$250(100 \%)$} \\
\hline
\end{tabular}

Table 7. Position of grammatical uses of structure types with no doubt in Present-day English

\begin{tabular}{lcccccc}
\hline Position & \multicolumn{2}{c}{ Adverbial no doubt } & \multicolumn{2}{c}{ there/it is no doubt } & \multicolumn{2}{c}{ I have no doubt } \\
& $\mathrm{n}$ & $\%$ & $\mathrm{n}$ & $\%$ & $\mathrm{n}$ & $\%$ \\
\cline { 2 - 7 } Initial & 35 & $29.5 \%$ & 68 & $93 \%$ & 26 & $86.5 \%$ \\
Medial & 68 & $57 \%$ & 0 & $0 \%$ & 0 & $0 \%$ \\
Final & 16 & $13.5 \%$ & 5 & $7 \%$ & 4 & $13.5 \%$ \\
\hline Total & 119 & $100 \%$ & 73 & $100 \%$ & 30 & $100 \%$ \\
\hline
\end{tabular}

6.1. Clausal structures

\subsubsection{There is no doubt}

The currently most frequent clausal pattern, there is no doubt, behaves syntactically much as it has always done. On the one hand, it may contain prepositional phrases, introduced by of (cf. Middle English example 10) or about (57), in which case it is always used lexically. On the other hand, it is - 
in the majority of cases - complemented by a clause, which is mostly a declarative, e.g. (59)-(61), but can be an interrogative, e.g. (58). The latter are almost always lexical, as a (real) question cannot be epistemically qualified (Nuyts 2001, 58). Examples with declarative that-clause can have lexical meaning, as in (59), which deals with beliefs and facts about fluoride. Like (5) above, (59) exemplifies the lexicalized idiom whose meaning can be glossed as 'there is general agreement'. Most examples with declarative complement, however, have the grammatical meaning of certainty, as in (60), which has remained constant since Middle English. The overall proportion of lexical(ized) versus grammaticalized uses is roughly $20 \%$ (19 tokens) versus $80 \%$ (73 tokens) in our data (see Table 6).

(57) [...] there is no doubt about the benefits of financial economics for professional investors [...] (WB)

(58) Though she didn't name Joyce, Carolyn or Trudi, the quartet were known to be fast friends. There could be no doubt in the minds of any who had a passing acquaintance with Arleen whom she'd written into her Satanic fantasies. (WB)

(59) $[\ldots]$ such preparations are used in certain cases of anaemia and even by some people who believe (though it isn't proven) that it will prevent their hair from greying. There is no doubt that fluoride is necessary for the healthy formation and growth of bones and teeth [...] (WB)

(60) Alain Prost proved you can take time out and make a great comeback when he won his fourth world crown driving for Williams in 1993. There is no doubt the constant testing and pressure of racing takes a hell of a lot out of you and a year away could make Hakkinen even more determined. He has certainly not looked the part this season. (WB)

\subsubsection{Have no doubt}

The less frequent clausal pattern have no doubt has also retained all its complementation patterns, which mirror those of there is no doubt. It may contain prepositional phrases (61) and is then used lexically. I have no doubt may also be followed by declarative propositions, in either lexical (62) or grammatical uses (63)-(66), or by interrogatives, which favour lexical meaning, as in (62). The overall proportions of lexical and grammatical uses are very similar in Present-Day English to those of there is no doubt, viz. 33\% (9 tokens) versus $77 \%$ (30 tokens) (see Table 6). 
(61) Published instead by Henry Colburn, it was even less successful than its predecessor; and, while its author had had "no doubt of its success", it aroused derision [...] (WB)

(62) Sir Ronnie said in a TV programme shown last night: "I have no doubt the IRA was involved in the murder of Charles Bennett. The Secretary of State has no doubt, and I have no doubt, what organisation was involved." (WB)

(63) "I want to follow in Glen's footsteps. If he had been given the chance in England, I have no doubt that he would have done well." (WB)

(64) With all the confidence of a brash 35-year-old, and despite the fact that I was a relative newcomer to the television industry, I had no doubt I could make TV-am into a success. (WB)

(65) "If I should cross his path, I will kill him," Xaform had said - darkly, but Khailin had laughed.

"If you should cross his path, I have no doubt that you will try," she said, "but Xaform, he would burn you to ashes."

(66) "[...] I thank you, Mister Sharpe," Cromwell said gravely, "for you have made my mind easier." [...].

Sharpe also stood, ducking his head under the low beams. "Thank you, sir."

"I've no doubt I'll see you at dinner soon [...]." (WB)

Semantically, grammaticalized I have no doubt largely continues to express the meanings it had developed by Late Modern English. Occasionally, it expresses full certainty, as in (63), but it mostly signals weaker degrees of certainty, verging on personal conviction (64). I have no doubt may still be used as a discourse marker, conveying ironic interpersonal stance (65), or involving the addressee in the dialogic interaction, as in (66), where the speaker signals he expects to see the addressee at dinner. However, in general, the shorter adverbial form seems to be preferred now as discourse marker (see Section 6.2), as is suggested by the disappearance of I have no doubt from medial position, where it often conveyed irony in Late Modern English.

\subsection{Adverbial}

The adverbial keeps the varied positional distribution (Table 7) and the scopal flexibility it had in Late Modern English, allowing it to modify only a part of the proposition, as in (67).

(67) People on gap years never spend weeks with exotic tribes learning about their culture. They go bungee jumping, trekking through 
rainforests or swimming with dolphins (and drunken swimming, no doubt). (WB)

Semantically, the adverbial also keeps all the functions it had developed in the earlier period. In some contexts, no doubt conveys certainty, for instance in concessive contexts such as (68), where the idea that some form of education is valuable is presented as generally acknowledged, but the drift of the argument goes against the construction of a new school building. The longer variant with no doubt of/about + anaphoric pronoun, e.g. (69), always expresses certainty; it is glossed in Sinclair et al. $(1994,496)$ as "you are certain it is true". More often, the adverbial is used in contexts that suggest less than full certainty. Example (70) is one such context, since the speaker's view is based merely on what his peep allows him to see. Alternatively, the evidence for the speaker's suppositions can also be earlier experience, such as the father's predictability that enables the speaker to guess at his intentions in (71). In this example, the adverb functioning as discourse marker is put at the end of the utterance to incite the addressee to confirm the proposition. In Present-day English, the adverbial has become the main discourse marker containing the string no doubt: it realizes interactional meanings and is often used to convey interpersonal stance such as irony, as in (67) and (71).

(68) $[\ldots]$ they were staggered at the scale of a proposed school building, ... For them it was an innovation too far. Some form of education among the workforce was no doubt valuable and even prudent; ... But what Owen had in mind seemed to them excessive. (WB)

(69) The last thing Benny could afford at this moment, ... was a full-scale inquiry linking the name Nogaro with more murders. Yet in the case of the boy and girl murder would have to be committed, no doubt about that. (WB

(70) With another heavy sigh, he ... risked a tiny peep through the Zoneof-Zone's slatted blinds. It was teeming with people down there, all of them journalists, no doubt. (WB)

(71) "Does your father know what it was like?" "Even if he did, he wouldn't care. Hablet has his own plans." "To invade Hythria, no doubt." Adrina looked around sharply, but Damin smiled. "Don't worry, Adrina. I won't overtax your ability to admit the truth any further, this night. Your father's worst fault is his predictability. His plans are easy enough to fathom." (WB)

\section{Concluding discussion}


This study set out to reconstruct the development of the modal and discourse marker uses of adverbial and clausal expressions with no doubt. Their history differs in a number of intriguing ways from that of the adverbial and clausal expressions with no question (Davidse and De Wolf 2012), which appear at first sight to be semantically and structurally very similar. Existential clauses with question emerged with compositional lexical meaning and positive polarity, then developed lexicalized uses of semi-fixed strings with negative polarity, and these negative idioms grammaticalized into modal modifiers. By contrast, existential expressions with negation + doubt emerged more or less instantaneously with grammatical modal meaning. Presumably, their cooptation to extraposition and parenthetical uses was facilitated by already existing instances of these patterns with grammatical meaning. Intriguingly, they developed lexicalized uses later in their development. The history of have/make doubt resembles that of make/have question more in that both originated as composite predicates with positive orientation, which then specialized for negative contexts, in which grammaticalized meaning developed. However, I have/make no doubt developed discourse marker uses in the wake of adverbial no doubt, which I have/make no question did not. To make sense of the peculiarities of the history of no doubt, we invoked Boye and Harder's discourse approach to grammaticalization and lexicalization as well as Kaltenböck, Heine and Kuteva's Thetical Grammar.

Even though Boye and Harder $(2007,592)$ initially mainly sought to account for the traditional trajectory from lexical to grammatical use of a clause with a complement-taking predicate such as (I) think, their theory can also accommodate the more quirky trajectory of there is no doubt. More recently, they $(2012,35-36)$ have pointed out that both grammaticalization and lexicalization involve the creation of a new conventionalized expression as part of an overarching change in the larger construction in which the new expression functions. The sudden emergence of zero/it/there is no doubt with grammatical, modal meaning in Middle English is a case of the creation of a conventionalized grammatical expression involving overarching change of the compositional constructions with be no doubt, meaning 'be no fear', that were in use at that time. The surprising trajectory from grammaticalized there is no doubt to lexicalized usage in Early Modern English can also be accounted for as the creation of a semi-fixed idiom, meaning 'there is general agreement'.

The development of discourse marker uses by adverbial no doubt and $I$ have no doubt fall within the explanatory range of Thetical Grammar. In Late Modern English, the adverbials were the first to be used as discourse markers, followed by I have/make no doubt, but not by there is no doubt. A general factor explaining the increasing use of adverbial no doubt as a discourse marker is economization, the "tendency toward brevity and compact 
(grammatical) marking caused by the growing demands of economy and informational compression (Hinrichs \& Szmrecsanyi 2007:469). As thetical constructions par excellence, the adverbials are syntactically and prosodically independent, and they are positionally mobile (Kaltenböck et al. 2011, 857). This intrinsically equips them to express functions oriented onto the discourse. The adverbial uses of no doubt started off expressing speaker attitude and then shifted to realizing speaker-hearer interaction $(2011,865)$. We proposed that the discourse marker uses were enabled by the great positional and scopal flexibility which no doubt acquired in Late Modern English. Its ability to construe both wide and narrow scope permitted it to relate to discourse units of varying sizes. No doubt can be used to invite a response from the addressee, coming close to an interrogative marker, or to express agreement to the preceding utterance. The routinization of no doubt in medial position seems to have been conducive to ironic uses, which interrupt the utterance with the speaker's appraising comment. The clausal structures then aligned with the adverbial's functions in accordance with the forms coding them. The impersonal structures there/it is no doubt have expressed certainty through all of their history and they have not developed discourse marker uses presumably because they do not refer to the speaker, to whom a personal supposition can be ascribed or who can involve the addressee in the communication. I make/have no doubt, which explicitly refer to the speaker, have a greater potential for rhetorical exploitation. This first manifested itself in imperative parenthetical clauses, in which the speaker tries to convince the addressee not to 'fear' (the original lexical meaning of doubt) or 'doubt'. Later I have/make no doubt copied the adverbial's discourse uses, increasing their parenthetical nature. However, in Present-day English, I have no doubt has lost its medial uses, has dropped in general frequency, and has seen its discourse marker uses decrease. Its formal behaviour has aligned more strongly with that of there is no doubt, leaving the adverbial as the thetical structure type amongst the no doubt expressions. Due to its positional and scopal flexibility and its brevity, the adverbial has now become the main realization of discourse marker uses.

\section{Acknowledgements}

This study was made possible by the postdoctoral mandate granted to An Van linden by FWO-Flanders Research Foundation (grant 1.2.767.11.N.00) and by GOA-project 12/007, "The multiple functional load of grammatical signs", awarded by the Research Council of The University of Leuven. It was further supported by grant no. HUM2007-60706/FILO of the Spanish Ministry of Education and Science and the European Regional Development Fund. Our 
particular thanks go to Irma Taavitsainen and Laurel Brinton and the two anonymous referees, whose very careful and incisive comments helped us remove many small infelicities and add many extra dimensions to the revised text.

\section{Notes}

1. All examples marked (WB) are extracted from WordbanksOnline and are reproduced here with the permission of HarperCollins.

2. Boye and Harder's $(2007,590)$ approach to grammaticalized clauses in terms of "coded discourse secondariness", identifiable by specific formal tests, differs both from analyses such as Thompson and Mulac (1991), which privilege usage over structure (Boye and Harder 2007, 574), and approaches such as Hopper and Traugott (2003, 208), which correlate the progressive grammaticalization of an erstwhile lexical matrix with process features such as that-deletion. In a similar vein, Simon-Vandenbergen (2007) views the presence of complementizer that, of auxiliaries, e.g. there can be no doubt, or of postmodifiers, e.g. there is no doubt about it, as arguments for lexical status. She concludes that "various factors indicate that there is no doubt has not, in contrast with I think, for example, developed into a modal particle" (Simon-Vandenbergen 2007, 23), but that similar "factors point to a further development of I have no doubt towards a parenthetical expression than there is no doubt (see Thompson and Mulac 1991 on the criteria for the grammaticalization of epistemic parentheticals)" (Simon-Vandenbergen 2007, 24). Against this, secondariness and nonaddressability characterize a grammatical element independently of process features such as entrenchment and provide a tool to assess the grammatical status of each individual use in its context. In our analysis of the no doubt data, the tests identified many examples of both there is no doubt and I have no doubt as grammatical. Secondary, grammatical uses of there be no doubt include some examples with that, e.g. (11), with auxiliaries, e.g. (50), and with postmodifiers, e.g. (45). Presence or absence of that has recently been argued to be an inconclusive indicator of the lexical or grammatical status of a complement-taking clause by Shank, Plevoets and Cuyckens (forthc.). Elements such as auxiliaries and postmodifiers - the latter also found with intrinsically modal adverbials such as (70) - can, in our view, function as intensifying elements of the grammatical meaning of the units in question. As pointed out by Boye and Harder $(2012,17)$, grammatical elements can be stressed. This lends them a certain "primariness", but not one in relation to their syntagmatic environment like lexical primariness. Rather, it involves paradigmatic prominence in implied contrast with other grammatical values. In a comparable way, auxiliaries such as can in (50) intensify the grammatical value of existential structures with no doubt, invoking a contrast with a contextually implied lesser degree of certainty.

3. For doubt, n.1 the OED mentions the following forms: dut(e), dote, doute, dowt(e), dought(e), dowght, dout, doubt(e), dubte, dowbt.

4. Our qualitative and qualitative analysis pertains only to these examples. 
5. We are strongly indebted to the anonymous referee who pointed out the existential reading of (10) and the possibility of an existential interpretation of it is no doubt in the Middle and Early Modern English examples.

6. For the PPCME examples, the source text is referred to by the title stencil of the Middle English Dictionary (MED), and the date of the manuscript is the one given in the MED. When not exact, MED dates are given by quarter century: $c$ (circa) indicates a date preceding or following the given date by 25 years and $a$ ('ante') indicates a date within the 25 years preceding the given date. A question mark indicates doubtful or uncertain information.

7. In the 1420-1500 data, there is one example that lacks subject and finite verb, but whose complementizer but marks it as an elliptical variant of an epistemic no doubt clause, as adverbials cannot take complementizers:

(i) How schuld pei suffyr yt? No dowt but pei xulde bope cry \& rore \& wrekyn hem $3 y f$ pei myth, \& ellys men wold sey pei wer no frendys.

'How should they suffer it [i.e. death]? No doubt that they should both cry and shout out, and avenge them [i.e. their friends] if they might, and else men would say that they were no friends.' (PPCME, (a1438) MKempe A (Add 61823) 71)

This elliptical variant, which inherently precedes the proposition, also differs from an adverbial in lacking its positional flexibility. We have subsumed this single occurrence under the existential clauses.

8. In Kaltenböck et al (2011) cooptation is restricted to the cognitive-communicative operation by which theticals are formed.

9. This is also shown by the fact that, when the complement clause is fronted, as in (16), there or it occur as subject of the postposed matrix.

10. As pointed out by an anonymous referee, the noun doubt itself has inherently negative semantics. What we mean here is that in the pattern have $+d o u b t$, the noun first occurs without negative quantifier no.

11. Simon-Vandenbergen $(2007,28)$ reports an earlier attestation of it is no doubt in the period 1250-1350, which suggests that the existential clause may have come first.

12. With regard to this point, we thank the anonymous referee who encouraged us to look for models of modal adverbials such as butan/no wene ('without/no hope/doubt') in Early English data.

13. Example (35) can be interpreted as first person free indirect speech: The whole learned world, I made no doubt, would rise to oppose my systems, (I thought). This explains why the parenthetical clause, which normally has present tense (p.c. Laurel Brinton), is shifted into a past tense.

14. Jucker et al. (2003) point out that "vague language" in conversation can serve the important function of inviting the partner's contributions. 
15. Traditionally, the development of discourse markers has been associated with movement to initial position and to increase in scope (e.g. Tabor and Traugott 1998). The case of no doubt reveals that movement to medial position and scope reduction can also facilitate the development of certain types of discourse marker uses.

\section{References}

Boye, Kasper, and Peter Harder. 2007. "Complement-taking Predicates: Usage and Linguistic Structure." Studies in Language 31: 569-606.

Boye, Kasper, and Peter Harder. 2012. "A Usage-based Theory of Grammatical Status and Grammaticalization.” Language 88: 1-44.

Breivik, Leiv. 1983. Existential There. A Synchronic and Diachronic Study. Bergen: University of Bergen.

Breivik, Leiv. 1990. Existential There. A Synchronic and Diachronic Study. $2^{\text {nd }}$ ed. Oslo: Novus Press.

Brinton, Laurel J. 2008. The Comment Clause in English. Syntactic Origins and Pragmatic Development. Cambridge: Cambridge University Press.

Brinton, Laurel J., and Minoji Akimoto. 1999. Collocational and Idiomatic Aspects of Composite Predicates in the History of English. Amsterdam and Philadelphia: John Benjamins.

Collins COBUILD English Dictionary. 1994. Ed. by John Sinclair. Birmingham: HarperCollins.

Davidse, Kristin, and Simon De Wolf. 2012. "Lexicalization and Grammaticalization: The Development of Idioms and Grammaticalized Expressions with No Question." Text \& Talk 32: 569-591.

De Smet, Hendrik. 2005. "A Corpus of Late Modern English Texts." ICAME Journal 29: 69-82.

De Smet, Hendrik. 2012. Spreading Patterns: Diffusional Change in the English System of Complementation. Oxford: Oxford University Press.

De Wolf, Simon. 2010. A question of no doubt. A synchronic-diachronic account of no doubt, no question and related expressions. MA thesis. University Leuven.

Halliday, Michael, and Ruqaiya Hasan. 1976. Cohesion in English. London: Longman.

Hinrichs, Lars, and Benedikt Szmrecsanyi. 2007. "Recent changes in the function and frequency of standard English genitive constructions: A multivariate analysis of tagged corpora." English Language and Linguistics 11: 437-474.

Hopper, Paul, and Elizabeth Traugott. 2003. Grammaticalization. $2^{\text {nd }}$ ed. Cambridge: Cambridge University Press. 
Huddleston, Rodney, and Geoffrey Pullum. 2002. The Cambridge Grammar of the English Language. Cambridge: Cambridge University Press.

Jucker, Andreas, Sara Smith, and Tanja Lüdge. 2003. "Interactive Aspects of Vague Language in Conversation.” Journal of Pragmatics 35: 1737-1769.

Kaltenböck, Gunther, Bernd Heine, and Tania Kuteva. 2011. "On Thetical Grammar." Studies in Language 35: 848-893.

Kroch, Anthony, and Ann Taylor. 2000. "Penn-Helsinki Parsed Corpus of Middle English, second edition." University of Pennsylvania. http://www.ling.upenn.edu/hist-corpora/PPCME2-RELEASE-3/index.html.

Kroch, Anthony, Beatrice Santorini, and Lauren Delfs. 2004. "Penn-Helsinki Parsed Corpus of Early Modern English." University of Pennsylvania. http://www.ling.upenn.edu/hist-corpora/PPCEME-RELEASE-2/index.html.

Lehmann, Christian. 2002. "New Reflections on Grammaticalization and Lexicalization." In New Reflections on Grammaticalization, ed. by Ilse Wischer, and Gabriele Diewald, 1-18. Amsterdam and Philadelphia: John Benjamins.

López-Couso, María José. 2006. "On Negative Existentials in Early English." In 'These things write I vnto thee ...': Essays in Honour of Björn Bakken, ed. by Leiv Egil Breivik, Sandra Halverson, and Kari Haugland, 175-187. Oslo: Novus Press.

López-Couso, María José. 2011. "Developmental Parallels in Diachronic and Ontogenetic Grammaticalization: Existential There as a Test Case." Folia Linguistica 45: 81-102.

Matthijs, Lennart, Kristin Davidse, An Van linden, and Lieselotte Brems. 2012. The development of mirative no wonder constructions. Paper presented at New Reflections on Grammaticalization 5, Edinburgh 16-19 July 2012.

Middle English Dictionary. 2002. Ed. by Francis McSparren. Michigan: University of Michigan. Available at http://ets.umdl.umich.edu/m/med/ (accessed 20 October 2012).

Mitchell, Bruce. 1985. Old English Syntax. 2 vols. Oxford: Clarendon Press.

Nuyts, Jan. 2001. Epistemic Modality, Language and Conceptualization: A Cognitive-pragmatic Perspective. Amsterdam and Philadelphia: John Benjamins.

Oxford English Dictionary. 1989. 2nd ed. (1993-1997), additions (2000-), 3rd ed. (in progress, online). Available at http://dictionary.oed.com/ (accessed 3 November 2012).

Quirk, Randolph, Sidney Greenbaum, Geoffrey Leech, and Jan Svartvik. 1985. A Comprehensive Grammar of the English Language. London: Longman.

Shank, Christopher, Koen Plevoets, and Hubert Cuyckens. forthcoming. "A Diachronic Corpus based Multivariate Analysis of 'I think that' versus 'I think zero'." In Polysemy and Synonymy. Corpus Methods and Applications 
in Cognitive Linguistics, ed. by Dylan Glynn, and Justyna Robinson.

Amsterdam and Philadelphia: John Benjamins.

Simon-Vandenbergen, Anne-Marie. 2007. "No Doubt and Related Expressions. A Functional Account." In Structural-Functional Studies in English Grammar: In Honour of Lachlan Mackenzie, ed. by Michael Hannay, and Gerard Steen, 9-34. Amsterdam and Philadelphia: John Benjamins.

Simon-Vandenbergen, Anne-Marie, and Karin Aijmer. 2007. The Semantic Field of Modal Certainty. A Corpus-Based Study of English Adverbs. Berlin: Mouton de Gruyter.

Tabor, Whitney, and Elizabeth Traugott. 1998. "Structural scope expansion and grammaticalization." In The Limits of Grammaticalization, ed. by Anna Giacalone Ramat, and Paul Hopper, 229-272. Amsterdam and Philadelphia: John Benjamins.

Taylor, Ann, Anthony Warner, Susan Pintzuk, and Frank Beths. 2003. "YorkToronto-Helsinki Parse Corpus of Old English Prose." University of York http://www-users.york.ac.uk/ lang22/YCOE/YcoeHome.htm.

Thompson, Sandra, and Anthony Mulac. 1991. "A Quantitative Perspective on the Grammaticization of Epistemic Parentheticals in English." In Approaches to Grammaticalization, ed. by Elizabeth Traugott, and Bernd Heine, Vol. II, 313-329. Amsterdam and Philadelphia: John Benjamins.

Traugott, Elizabeth. 1992. "Syntax." In The Cambridge History of the English Language. Vol. I: The beginnings to 1066, ed. by Richard Hogg, 168-229. Cambridge: Cambridge University Press.

Traugott, Elizabeth. 2008. "Grammatikalisierung, emergente Konstruktionen und der Begriff der 'Neuheit' [Grammaticalization, Emergent Constructions and the Notion of 'Newness']." In Konstruktionsgrammatik II: Von der Konstruction zu Grammatik, ed. by Kerstin Fischer and Anatol Stefanowitsch, 5-32. Tübingen: Stauffenburg.

Traugott, Elizabeth, and Richard Dasher. 2002. Regularity in Semantic Change. Cambridge: Cambridge University Press.

Van linden, An. 2012. Modal Adjectives: English Deontic and Evaluative Constructions in Diachrony and Synchrony. Berlin: De Gruyter Mouton.

Visser, Frederik Theodoor. 1970. An Historical Syntax of the English Language. Part One Syntactical Units with One Verb. $2^{\text {nd }}$ impression. Leiden: Brill.

Authors' addresses

Kristin Davidse

Department of Linguistics, University of Leuven 
Blijde Inkomststraat 21, PO Box 3308

B-3000 Leuven

Belgium

kristin.davidse@arts.kuleuven.be

Simon De Wolf

Department of Linguistics, University of Leuven

Blijde Inkomststraat 21, PO Box 3308

B-3000 Leuven

Belgium

simon_dewolf@hotmail.com

An Van linden

Department of Linguistics, University of Leuven

Blijde Inkomststraat 21, PO Box 3308

B-3000 Leuven

Belgium

an.vanlinden@arts.kuleuven.be

\section{About the authors}

Kristin Davidse is professor of English Linguistics at the University of Leuven. She has published in international journals and volumes on the semantics of clause constructions and on grammaticalization in the NP in English.

Simon De Wolf is a research student from the University of Leuven. His main interest is the diachronic development of modal modifiers (there is)/(I have) no question/doubt, on which he has presented papers at international conferences.

An Van linden is a postdoctoral researcher in the Department of Linguistics at the University of Leuven. Her research interests include the analysis of clause combining, mood and modality, information structure and grammaticalization in the NP, in the Germanic languages as well as in typologically diverse languages. 